\title{
The Autonomy of Treaty Terms ${ }^{1}$
}

In accordance with the conception of the autonomy of treaty terms, an international body exercising monitoring functions should assign treaty terms specific meanings, irrespective of the meanings they have in the national law of particular State parties.

International monitoring involves the comparison of a treaty norm establishing a given human right with a respective norm of national law. Both norms are often worded in a similar or identical manner. The identical or similar wording of a treaty norm and a corresponding national norm does not entail that meanings assigned to terms used in them are identical, however. This is due to the fact that they are interpreted by different bodies. ${ }^{2}$ The reasons for divergent interpretations are many. For instance, the general provisions of the International Covenant on Civil and Political Rights on the protection of minorities (Article 27) or on political rights (Article 25) are more susceptible to divergent interpretations than the detailed and precise provisions on the administration of justice (Article 14). Firstly, it must be remembered, however, that national law

1 A. Michalska, Autonomiczność pojęć traktatowych, "Toruński Rocznik Praw Człowieka i Pokoju” 1993, 2 by Tomasz Żebrowski and proofread by Stephen Dersley and Ryszard Reisner. The translation and proofreading were financed by the Ministry of Science and Higher Education under 848/2/P-DUN/2018.

2 V. P. Daranowski, Międzynarodowa ochrona praw obywatelskich i politycznych in statu nascendi. Międzynarodowy Pakt Praw Obywatelskich i Politycznych, Łódź 1993, p. 240. Author develops the theory of objective regime against the backdrop of the discussion of the autonomy of treaty terms. 
is enacted through reliance on specific philosophical, political and legal conceptions that determine what this law means and how it should be interpreted. Agreement on the content of international instruments is not underpinned by a common conception of human rights. Consequently, provisions on the freedom of speech or the freedom of association are considerably more often subject to divergent interpretations than, for example, provisions on personal freedom or a ban on torture.

The autonomy of certain terms is sometimes provided for in treaties themselves. For instance, the provisions of the European Convention on Human Rights on the freedom of assembly and association (Article 11(1)), by establishing the right to form and to join trade unions, pre-determine that the trade-union freedom is covered by this provision, regardless of whether trade unions are considered associations by national law. An analogous wording has been adopted by the drafters of the Covenant on Civil and Political Rights in its Article 22(1).

The decisions of international bodies monitoring how signatories implement human rights treaties show a rather clear tendency to assign the terms used in the treaties an autonomous meaning. In the decisions of the Human Right Committee, the tendency was first observed in relation to the application of Sandra Lovelace v. Canada. ${ }^{3}$ The Committee took the position that it was necessary to differentiate between the protection of minorities provided for under the Indian Act and the international protection of minorities guaranteed under the Covenant, Article 27. As a result, the Committee held that in spite of the fact that the Indian Act guaranteed a number of rights and privileges for members of ethnic groups, there were no justifiable reasons for denying the author of the application the rights provided for in the Covenant, Article 27. This decision is cited in an illustration of the thesis that “... the protection provided for under the Covenant is international protection which is to be distinguished from national standards of protection”. ${ }^{4}$

3 Communication no. 6/24, Rapport du Comité des Droits de l’Homme, Assemblée Générale, Documents Officiels, 1981.

4 B. G. Ramcharan, The Concept and Present Status of the International Protection of $\mathrm{Hu}$ man Rights, Dordrecht-Boston-London 1989, p. 31. 
In relation to the case of Gordon C. van Duzen v. Canada, the $\mathrm{Hu}-$ man Rights Committee found that:

The Committee further notes that its interpretation and application of the International Covenant on Civil and Political Rights has to be based on the principle that the terms and concepts of the Covenant are independent of any particular national system of law and of all dictionary definitions. Although the terms of the Covenant are derived from long traditions within many nations, the Committee must now regard them as having an autonomous meaning.

The object of interpretation was the term "penalty" within the meaning of the Covenant, Article 15(1). The question at issue was whether the term also covered “administrative” penalties. The Committee, opting for an extensive interpretation, stressed that it took into consideration not only the literal wording of the relevant provision, but also its object and purpose. ${ }^{5}$

The conception of the autonomy of treaty terms can also be easily found in the decisions of the European Commission of Human Rights and the European Court of Human Rights. An example of this is provided by the interpretation of Article 11, mentioned previously, of the European Convention on Human Rights, which establishes the freedom of assembly and association. Article 11 stipulates that political parties are treated as associations, regardless of whether they enjoy this status under national law. This position was taken by the European Commission of Human Rights in relation to the application by the German Communist Party v. the Federal Republic of Germany, which questioned whether the decision to ban the party was compliant with the European Convention. ${ }^{6}$ P. van Dijk and G.J.H. van Hoof write that:

5 Communication no. 12/50, Rapport du Comité des Droits de l'Homme, Assemblée Générale, Documents Officiels, 1982.

6 Application no. 250/57, Yearbook of the European Convention on Human Rights, 19551957, p. 222. 
An autonomous meaning should be assigned to the word "association". The legal form chosen, and the legal consequences attached thereto by national law, cannot be decisive here, since otherwise the guarantee provided for in Article 11 would be illusory and the scope of the guarantee granted in particular State parties would differ. ${ }^{7}$

This is not only a theoretical demand, but also a conclusion following from a study of the decisions of European bodies.

In the cases referred to above by way of example, international bodies recognised the autonomy of the meanings of treaty terms vis-à-vis national law systems. A question arises, however, of whether national law is the only point of reference for assigning treaty terms autonomous meanings, or whether such a reference point is afforded also by other human rights treaties. In other words, is a given treaty to be interpreted as an autonomous instrument or as one of the elements in the international system of human rights protection. It is by no means just a theoretical problem; on the contrary, it has arisen in relation to the varied practice of international bodies.

European case law refers to treaties binding on the state-members of the Council of Europe and to both Human Rights Covenants and ILO Conventions. For instance, the phrase "forced or compulsory labour" (European Convention, Article 4) was interpreted by the European Court of Human Rights in the light of the provisions of ILO Conventions nos. 29 and 105. ${ }^{8}$ When interpreting trade-union freedom, European bodies have regularly referred to relevant ILO Conventions. For instance, the European Commission maintained - referring to ILO Convention no. 87-that the freedom of assembly and association guaranteed in Article 11 of the European Convention, meant that any form of intimidating employees to stop them from par-

7 P. van Dijk, G.J.H. van Hoof, Theory and Practice of the European Convention on Human Rights, Deventer-Boston 1990, p. 431.

8 Judgement of ECHR of 23 November 1983, Van der Mussel v. Belgium, European Court of Human Rights, Judgements and Decisions Series A, vol. 70, 1983, pp. 16-17. 
ticipating in trade-union activity was a breach of this freedom. ${ }^{9}$ The Commission took the position that the right to form trade unions included, inter alia, the right of unions to draw up their own rules and to make decisions on trade-union matters. These rights are explicitly recognised in ILO Convention no. 87 , which "must be taken into account in the present context". ${ }^{10}$

The most troublesome problem in the context of trade-union freedom was the right to strike. The organs of the European Convention recognised, admittedly, that strikes were an important means of protecting trade union interests, but not the only one. The Court, invoking the European Social Charter, held that the right to strike-assuming that it is guaranteed under Article 11 of the European Convention —could be always restricted by national legislation. ${ }^{11}$

The Human Rights Committee did not invoke-besides the lastmentioned case-other international instruments. The Committee, however, heard many applications involving decisions on pensions, unemployment benefits, and state subsidies to cover tuition in private schools, that is, ones whose subject matter went beyond the scope of the Covenant on Civil and Political Rights. The authors of these applications alleged that the principle of equality before the law had been breached (Covenant, Article 26).

Article 26 of the International Covenant on Civil and Political Rights states: "All persons are equal before the law and are entitled without any discrimination to the equal protection of the law". The Committee has consistently held that this provision is not a repetition of the guarantees given in Article 2(1) that obligates State Parties to respect and ensure to all individuals "rights recognized in the present Covenant, without distinction of any kind...". The Committee has held that Article 26 of

9 X v. Ireland, Application no. 4125/69, Yearbook of the European Convention on Human Rights, Vol. XVI, 1971, p. 198.

10 Cheall v. United Kingdom, Application no. 10550/83, Decisions and Reports of the European Commission of Human Rights, 1985, p. 185

11 Judgement of ECHR of 6 February 1976, Schmidt \& Dahlström v. Sweden, Judgement delivered by the Court on 6 February 1976, European Court of Human Rights Series A, vol. 21, 1976, p. 16. 
the Covenant imposed a ban on "discrimination in all spheres that fall within the competence of state organs and not only in respect of rights provided for in the Covenant".

Characteristically, in cases alleging infringement of the International Covenant on Civil and Political Rights, Article 26, in relation to decisions on social matters, the Committee did not invoke the Covenant on Economic, Social and Cultural Rights, whereas the parties to disputes did. It will be worthwhile to present here, by way of example, arguments given by individuals and States, and grounds for the Committee's decision, as they have several interesting aspects.

A female Dutch national, Broeks, alleged the infringement of Article 26 of the Covenant by arguing that a decision of competent state organs to deprive her of an unemployment benefit was tantamount to discrimination by reason of sex. Under national legislation, a male in an identical personal and social situation is paid such a benefit. The ratio legis of these provisions was the fact that a male was held to be the main breadwinner.

The State questioned the admissibility of ratione materiae application by arguing that (a) the principle of non-discrimination in the area of social security and insurance is guaranteed in Articles 2 \& 3 (equality of rights) and Article 9 (right to insurance) of the Covenant on Economic, Social and Cultural Rights; (b) the Dutch government applied these provisions in compliance with Article 2(1) of the Covenant that obligates State Parties only to undertake "steps [...] to the maximum of its available resources, with a view to achieving progressively the full realization of the rights"; (c) the process aimed at achieving progressively the full realization of the rights was well under way and discriminatory provisions were gradually being eliminated from legislation; (d) the International Covenant on Economic, Social and Cultural Rights put in place its own system of monitoring and the Netherlands periodically submitted the required reports.

What follows is the commentary submitted by the author of the application. The preambles to both Covenants stress a close connection 
and relationship between civil and political rights, on the one hand, and social and economic ones, on the other. The fact that these two categories of rights are guaranteed by separate international instruments does not weaken these connections. Article 26 of the International Covenant on Civil and Political Rights, laying down the overall principle of equality before the law, does not relate it — unlike Article 2(1) — to the rights provided for in the Covenant. Furthermore, the Dutch legislator, in the grounds attached to its ratification resolution maintained that "the provisions of Article 26 are applied also in areas not covered by the Covenant”. When the Human Rights Committee was discussing a periodical report submitted by the Netherlands, the Dutch representative said that Article 26 of the Covenant was also applicable to economic, social and cultural rights. In the light of this statement of the government representative, all that could be debatable was the question of direct application of Article 26 by the courts. It is also worth mentioning that the author of the application, arguing in favour of a close connection between the two categories of human rights, invoked not only the preambles to both Covenants, but also a 1950 resolution of the UN General Assembly that had outlined the main principles of the future Covenants.

The Committee held that equal treatment in the area of social rights did not differ at all from equal treatment in the area of civil and political rights, and that a different interpretation would make Article 26 of the Covenant an idle declaration. Consequently, finding that the varying of benefits had no rational grounds, i.e. it was arbitrary, the Committee ruled that Article 26 of the Covenant on Civil and Political Rights had been infringed. ${ }^{12}$

In an analogous case, the Netherlands enhanced its arguments by claiming that the State was not obligated to eliminate all discriminatory provisions from its national law. It was maintained that time was necessary to perform a comprehensive analysis of legislation.

12 Cf. S.W.M. Broeks v. the Netherlands, Application no. 172/1984, Rapport du Comité des Droits de l’Homme, Assemblée Générale, Documents Officiels, 1987. 
Moreover, changes in morals, ethical standards and public policies may make certain distinctions, once acceptable, look discriminatory. The author of the application invoked in her submissions the statement by the Dutch government submitted at the ratification of the Covenant. In it, it was maintained that the period of legislation adjustment did not apply to the norms that could be directly applied. One of them, unsurprisingly, is the norm laid down in Article 26 of the Covenant, which is borne out by the practice of the Dutch courts followed hitherto. The Committee expressed the view that Article 26 of the Covenant had been violated, because the distinction drawn between women and men in their entitlement to an unemployment benefit was unreasonable and irrational. ${ }^{13}$

It transpired that the Committee found that the distinctions made in social insurance benefits were not discriminatory, as for instance between spouses and unmarried persons cohabiting together. ${ }^{14}$ Importantly, however, the Committee did not find such applications to be inadmissible ratione materiae.

The pretext for filing applications in the cases cited above was, admittedly, the protection of the principle of equality before the law, but the result of the monitoring procedure was the restoration of social and economic rights to an individual. What is more, the State announced that it would make amendments to its national legislation. One can wonder if these precedents related to Article 9 of the Covenant on Economic, Social and Cultural Rights open the door to the procedure before the Human Rights Committee for protecting other rights provided for in the Covenant. This is even more likely as in connection with the principle of equality before the law, the authors of the applications invoked other rights as well. In none of these cases, however, did the Committee cite the Covenant on Economic, Social and Cultural Rights, or other

13 F. G. Zween-de Vries v. the Netherlands, Application no. 182/1984, Rapport du Comité des Droits de l'Homme, Assemblée Générale, Documents Officiels, 1987.

14 L. G. Danning v. the Netherlands, Application no. 180/1984, Rapport du Comité des Droits de l’Homme, Assemblée Générale, Documents Officiels, 1987. 
treaties for that matter. It did so for the first time in the case referred to below.

Several Canadian public employees filed an application, claiming a breach of the Article 22 of the Covenant (freedom of association). They alleged that the statutory prohibition of a strike by public employees contravened the provision in question. The alleged victims of the statute, which imposed penalties for participating in a strike, were-in the opinion of the application authors-members of the trade union of public employees.

Several years earlier, the trade union of which the application authors were members, had lodged a complaint with the Committee on Freedom of Association of the International Labour Organization (ILO), alleging that the statutory prohibition breached ILO Convention no. 87 since "it constituted a considerable restriction on the opportunities open to trade unions to further and defend the interests of their members". The Committee on Freedom of Association suggested that the legislation in question be amended and the prohibition of strike be confined only to "essential services". The trade union lodged complaints twice with the ILO in later years, because the legislation had not been amended.

In the proceedings before the Human Rights Committee, the State raised in the first place the allegation of inadmissibility of a ratione materiae application. The Canadian government took the stance that Article 22(1) of the Covenant-which enacts the right for everyone "to form and join trade unions for the protection of his interests"- did not guarantee the right to strike. A State party is only obliged to permit and make possible trade-union action. However, in giving effect to this obligation, a State party is free to choose the means that it considers appropriate. Interestingly enough, the Canadian government cited the Covenant on Economic, Social and Cultural Rights, Article 8(1)(d), which provides for the right to strike but used this provision as an argument for the inadmissibility of a ratione materiae application. 
In their commentary to the statement by the State, the application authors invoked Article 22(3) of the Covenant, which says:

\begin{abstract}
Nothing in this article shall authorize States Parties to the International Labour Organisation Convention of 1948 concerning freedom of association and protection of the right to organize to take legislative measures which would prejudice, or to apply the law in such a manner as to prejudice, the guarantees provided for in that Convention.
\end{abstract}

The Committee, considering the admissibility of the application, in the first place posed the question of whether Article 22 of the Covenant guaranteed the right to strike. This was its line of reasoning: since the right to strike is not guaranteed expressis verbis, the interpretation of this provision should answer the question of whether the right to form trade unions implies the right to strike. The Committee admitted that on the grounds of the ILO Convention and the decision of the Committee on Freedom of Association quoted above, the right to form trade unions implied the right to strike. The Committee continued:

The Human Rights Committee has no qualms about accepting as correct and just the interpretation of those treaties by the organs concerned. However, each international treaty, including the International Covenant on Civil and Political Rights, has a life of its own and must be interpreted in a fair and just manner, if so provided, by the body entrusted with the monitoring of its provisions.

The Covenant on Economic, Social and Cultural Rights provides for the right to form trade unions and the right to strike (Article 8). Having analysed in detail the drafting of both Covenants, the Committee concluded that the drafters of the Covenant on Civil and Political Rights had consciously and purposefully left out the right to strike from its Ar- 
ticle 22. Consequently, it decided that the application was inadmissible ratione materiae. ${ }^{15}$

As many as five Committee members signed an individual opinion. They believed that the intentions of the drafters of the provisions of both Covenants under discussion were not absolutely clear. In favour of the admissibility of the application, they offered two main arguments. First, to further and defend trade-union member interests, various means are used, none of which is listed in Article 22 of the Covenant on Civil and Political Rights. Hence, any means similar to a strike could be questioned. Second, there are no reasons to interpret the right to form trade unions, provided for in both Covenants, differently. Nor are there any reasons for the Committee to understand the right to form trade unions differently than the International Labour Organization does, especially in the light of Article 22(3) of the Covenant quoted above.

The line of reasoning presented in the individual opinion merits complete approval. The Committee based its decision on a formal-dogmatic interpretation of Article 22 of the Covenant, while it should have adopted a teleological interpretation. Social and economic rights are taken into consideration in the General Comments when they discuss, for instance, State obligations in relation to the reduction of infant mortality rate or the elimination of hunger and malnutrition, etc.

The Committee has invoked other international instruments when considering reports, for instance, the Convention against Torture and Other Cruel, Inhuman or Degrading Treatment or Punishment (in relation to Article 7 of the Covenant) and the Standard Minimum Rules for the Treatment of Prisoners (in relation to Articles $7 \& 10$ ). Hence, there are no reasons for ignoring other treaties when considering individual applications.

The conception of autonomy of treaty terms vis-à-vis the national law of State parties is understandable and necessary. An international body must apply a "supranational” interpretation in the name of the universal nature of

15 J. B. et al. v. Canada, Application no. 118/1982, Rapport du Comité des Droits de l’Homme, Assemblée Générale, Documents Officiels, 1986. 
human rights, which may have a regional or global dimension. The segregation, in turn, of human rights by the international instrument in which they are provided for is artificial and incompatible with the idea of the indivisibility of all human rights. Finally, this author believes that the autonomy of a treaty from other international instruments is a misguided legal construct.

\section{Literature}

Ramcharan B.G., The Concept and Present Status of the International Protection of Human Rights, Dordrecht-Boston-London 1989.

Daranowski P., Międzynarodowa ochrona praw obywatelskich i politycznych in statu nascendi. Międzynarodowy Pakt Praw Obywatelskich i Politycznych, Łódź 1993.

Broeks v. the Netherlands, Application no. 172/1984, Rapport du Comité des Droits de l'Homme, Assemblée Générale, Documents Officiels, 1987.

Cheall v. United Kingdom, Application no. 10550/83, Decisions and Reports of the European Commission of Human Rights, 1985.

Communication no. 12/50, Rapport du Comité des Droits de l'Homme, Assemblée Générale, Documents Officiels, 1982.

Communication no. 250/57, Yearbook of the European Convention on Human Rights, 1955-1957.

Communication no. 6/24, Rapport du Comité des Droits de l’Homme, Assemblée Générale, Documents Officiels, 1981.

Danning L.G. v. the Netherlands, Application no. 180/1984, Rapport du Comité des Droits de l’Homme, Assemblée Générale, Documents Officiels, 1987.

Dijk P. van, Hoof G.J.H. van, Theory and Practice of the European Convention on Human Rights, Deventer-Boston 1990.

J.B. et al. v. Canada, Application no. 118/1982, Rapport du Comité des Droits de l’Homme, Assemblée Générale, Documents Officiels, 1986. 
Judgement of ECHR of 23 November 1983, Van der Mussel v. Belgium, European Court of Human Rights, Judgements and Decisions Series A, vol. 70, 1983.

Judgement of ECHR of 6 February 1976, Schmidt \& Dahlström v. Sweden, Judgement delivered by the Court on 6 February 1976, European Court of Human Rights Series A, vol. 21, 1976.

X v. Ireland, Application no. 4125/69, Yearbook of the European Convention on Human Rights, Vol. XVI, 1971.

Zween-de Vries v. the Netherlands, Application no. 182/1984, Rapport du Comité des Droits de l’Homme, Assemblée Générale, Documents Officiels, 1987. 
